sidered in detail, and the mode of occurrence of the Awaruite in them and in the sands derived from their denudation is discussed. The author submits a sketch-map of the localities where the mineral has been discovered in sand, including not only George River, but also Silver Creek, Red Hill, and other localities, and quotes Mr. Paulin's belief that it occurs diffused through the whole extent of peridotite and serpentine rocks, and inferentially in the drifts derived therefrom.

OBITUARY.

JOHN GUNN, M.A., F.G.S.,

Formerly Rector of Irstead and Barton Turf, in Norfolk.

Born October 9Th, 1801 ; Died MaY 28Th, 1890.

Bx the death of Mr. John Gunn, geological science has lost one of her most devoted and enthusiastic disciples. Born October 9th, 1801, he lived to the advanced age of 88 , and was thus one of the last links between the geologists of the present day and those who laid the foundations of the science.

His father, the Rev. William Gunn, Rector of Irstead and Barton Turf, in Norfolk, was a man of considerable literary attainments, and nore especially devoted to History and Archæology, but taking very little interest in the pursuit of Natural Science.

In an address delivered to the Norwich Geological Society in 1869, John Gunn thus speaks of his early years:- "When at school he was more interested in Natural History than in the Latin Grammar, and his father put the books he was most anxious to study at the top of the library, so that they might be out of his reach. $\mathrm{He}$, however, took every convenient opportunity to get at a volume of Buffon, and thus he gathered some knowledge respecting the habits and the habitat of animals. He could never forget, and he could not describe the electric effect produced upon him by the discovery of the fossil remains of the Elephant, Rhinoceros, and Hippopotamus in the Forest Bed at Happisburgh, otc. He then asked his father how these creatures, now living in tropical countries, could have existed in this? And he received an answer which was still fresh in his memory, and which constantly recurred to him, "There is much to be done before that can be made out." " 1 This question probably was put about the year 1822 , when R. C. Tavlor published his account of Fossil Bones on the Coast of East Norfolk. It must have been soon after this date that John Gunn made the acquaintance of Samuel Woodward, from whom he derived his earliest lessons in geology; moreover his local researches were no doubt stimulated by intercourse with his neighbours, the Rev. James Layton, of Catfield, and Miss Anna Gurney, of North Repps, both of whom became ardent collector's of the fussil mammalia from the Forest Bed.

On the death of his father in 1841, John Gunn, who had been

1 “Norwich Mercury," Feb. 10, 1869. 
Chaplain to H.R.H. the Duke of Sussex, was appointed to the rectory, and for many years his home was at Irstead.

By his marriage with Harriet, a daughter of Dawson Turner, F.R.S., of Yarmouth, he became brother-in-law of Sir W. J. Hooker, and Sir Francis Palgrave. Mrs. Gunn was a talented artist, and accompanied her husband over many parts of Norfolk, their attention being in early years mainly given to archæological studies; geological subjects, however, in turn, attracted attention, and we find in Lyell's "Elements of Geology" an illustration of the Chalkpit at Horstead, with its paramoudras, from a drawing made by Mrs. Gunn in 1838.

From about the year 1850 until the close of his life, John Gurn's energies were very largely devoted to geology, and in particular to the vertebrate remains of the Forest Bed. He gathered together a very fine collection of the fossils, which he presented in 1868 to the Norfolk and Norwich Museum.

His observations on the geology of Norfolk were brought together in a Sketch, published in 1864, in White's History and Directory of the County. A fourth edition of this article, which was reprinted for private circulation, was issued in 1883, and it was Mr. Gunn's intention to publish the same in a separate and extended form, a task in which he had been diligently engaged to within a few months of his death.

Mr. Gunn took an active part in the formation of the Norfolk Archæological Society. In April, 1864, the Norwich Geological Society was founded, Mr. Gunn being elected President, and Mr. J. E. Taylor, Secretary. Until 1878 , the reports of the meetings were published in the local newspapers, but a summary of these (with references) was printed in the first part of the "Proceedings" of the Society commenced in 1878." During this period $\mathrm{Mr}$. Gunn contributed frequent accounts of recent discoveries, and also remarks on various subjects, more especially dealing with the Mammaliferous Stone-bed at the base of the Norwich Crag, the relations of the Norwich Crag and Forest Bed to the Chillesford Clay, and the prospect of finding productive Coal-measures in Norfolk and Suffolk. Many excursions were made by the Society to different parts of the county, and at the annual meetings an account of what had been done during the year was given by the President.

Mr. Gunn also contributed an occasional paper to the Geological Society of London, and to the Geologists' Association. While, however, he was always ready and rejoiced to take up the hammer and go into the field, and to communicate all his information to others, he manifested no great eagerness to publish. Thus it has been that much of his work is embodied in the writings of others, who have acknowledged their indebtedness to him. The recognition of an Upper and Lower Boulder Clay, separated by a mass of sand, to be seen on the coast near Yarmouth and Lowestoft, was due to Mr. Gunn, but published (with acknowledgment) by Joshua

1 Only one volume has been published, 1878-84; the Society is now merged with the Norfolk and Norwich Naturalists' Society. 
Trimmer. ${ }^{1}$ The distinction between the Post-Glacial Mundesley River-bed and the older Forest Bed Series was first perceived by Mr. Gunn. ${ }^{2}$ His collection of fossil mammalia, and especially the specimens of Elephant, proved of much service to Falconer and Leith Adams; the former remarks that "The interest and value of his collection are only equalled by the liberality with which he makes it available for the ends of science. I need only say in illustration that he has placed all the specimens in his possession at $m y$ disposal for this essay, even to be sawn up for sections, if necessary, or for any other use to which they could be turned." 3

Mr. Gunn's enthusiasm may be well realized when it is remembered that (in 1888) when 87 years of age, he attended the London meeting of the International Geological Congress, and subsequently paid a visit to St. Erth, in Cornwall, to examine the Pliocene Beds that have been discovered in that neighbourhood.

Notwithstanding his devotion to geology, Mr. Gunn, while rector of Irstead, was very energetic in the pursuit of his clerical duties, and filled the position of Rural Dean.

In 1869, after forty years' service in the Church, he resigned his preferment, and ultimately quitted the ministry. This he did because he became convinced that he could no longer conscientiously preach some of the doctrines of the Church of England. In his published letter to his parishioners, he remarks: "It was a hard wrench for me to part from the place of my birth, the scenes of childhood, and of a mature and happy life; from a charming spot where almost every tree and shrub had been planted by myself; and, above all, from parishioners between whom and myself there ever had subsisted a most cordial feeling of good will."

Mr. Gunn died May 28th, 1890, and was buried at the Rosary, Norwich.

\section{WILLIAM SWEETLAND DALLAS, F.L.S.}

Born 31 St J J

IT is with deep regret we have to record the death of Mr. W. S. Dallas, the able and accomplished Assistant-Secretary of the Geological Society of London; a man universally esteemed and beloved by all, and one whose loss to science it will be difficult to supply.

William Sweetland Dallas was the youngest son of Mr. William Dallas, belonging to an ancient Scottish family, an East India Merchant and a Member of Lloyds', who died in 1842.

Born in Islington, January 31st, 1824, he early evinced a love of Natural History, and when only a boy made collections of Insects with his elder brother in the fields of Hampstead, Highgate, and Hornsey.

1 See J. H. Blake, Geol. Yarmouth and Lowestoft (Geol. Surv.), p. 28.

2 Lyell, Antiq. Man, Fourth Edition, p. 267.

3 Quart. Journ. Geol. Soc. vol. xxi. p. 299. See also E. T. Newton, Vertebrata - of the Forest Bed Series, 1882 . 